\section{Alcohol use and falls among the elderly in Metropolitan São Paulo, Brazil}

\author{
Consumo de álcool e ocorrência de quedas \\ entre idosos na Região Metropolitana \\ de São Paulo, Brasil
}

\author{
de Botucatu, Universidade \\ Estadual Paulista "Júlio de \\ Mesquita Filho", Botucatu, \\ 2 Faculdade de Medicina de \\ Ribeirão Preto, Universidade \\ de São Paulo, Ribeirão Preto, \\ 3 Departamento de Ciências \\ Correspondence \\ M. C. P. Lima \\ Departamento de Neurologia \\ e Psiquiatria, Faculdade \\ de Medicina de Botucatu, \\ Universidade Estadual \\ Paulista "Júlio de Mesquita \\ Filho". \\ Distrito de Rubião Jr. \\ Botucatu, SP \\ 18618-000, Brasil. \\ mclima@fmb.unesp.br
}

\begin{abstract}
${ }^{1}$ Faculdade de Medicina
Brasil. Brasil. da Saúde, Universidade Federal de São Paulo, São Paulo, Brasil.
\end{abstract}

\begin{abstract}
,
\end{abstract}


te of these higher risks, it is estimated that $9 \%$ of elderly people in the USA have an unhealthy drinking habit 7 .

Even though alcohol-related problems are quite frequent in Brazil, the extent of these problems among the elderly remains unknown. Brazilian general population surveys have targeted younger people, and therefore the small number of older people in the samples reduces the statistical power of analyses related to them. In Brazil, with regional samples, authors have estimated the prevalence of harmful drinking among elderly people to be between $4.3 \%$, in both genders 8 , and $27 \%$, just among men 9 . In a cross-sectional analysis of nationally representative data, Laranjeira et al. 10 observed about a ten per cent prevalence of harmful drinking in Brazil.

The harmful use of alcohol can be related with many health problems, including falls. According to information from the Centers for Disease Control and Prevention (CDC), in the USA falls ranked as the second most significant cause of death for people aged between 55 and 74, and first for those over that age bracket 11 . Sorock et al. 12 analyzed causes of death related to alcohol in the USA, in a case-control study. They found that drinking five drinks or more per sitting was strongly associated with deaths due to falls, as well as with car accidents and suicide. This drinking pattern increased the risk of death by $70 \%$ due to those causes, even after adjustments for age, gender, education and employment in the year previous to the interview ${ }^{12}$. Although it has been described at length in other countries 13 , the association between alcohol use and falls has not been sufficiently explored in Brazil. There has been just one case-control study that researched into falls and alcohol use in Brazil 14. This study aimed to identify risk factors for falls related to severe fractures among the elderly, but it did not find associations with regular alcohol use.

This study was conceived in view of the absence of information about a possible association between alcohol use and falls among the elderly in Brazil. Its aims are: (a) to identify the pattern of alcohol use in subjects aged 60 years and over in a general population sample from the Metropolitan Area of São Paulo city, Brazil, and (b) to analyze its possible association with falls in the year previous to the interview. The hypotheses are advanced that alcohol consumption use among elderly women is lower than among elderly men, and that the pattern of alcohol use and falls are associated.

\section{Methodology}

This study is part of the international Gender, Alcohol, and Culture: an International Study (GENACIS project), a collaborative study with Pan American Health Organization (PAHO) support, conducted in different countries, among them Brazil.

This cross-sectional study is based on the general population of the Metropolitan Area of São Paulo city. According to data from the Instituto Brasileiro de Geografia e Estatística (IBGE - Brazilian Institute of Geography and Statistics), in 2005 it had a population of 19,130,455 inhabitants, of which about $50 \%$ were aged 18 years and above. The area itself comprises the capital city of São Paulo State plus another 38 counties, with a population of about two thirds of the whole State. Additional details about sampling can be found in the PAHO report 15.

\section{Sample}

The sampling was obtained through a two-stage randomization: initially the census sector was selected randomly with probability proportional to size sampling. The households were then randomly selected as well. In this way, the sampling unit was the household, in which all persons aged 18 years and above, from the appropriate selected gender, could be interviewed. The sample size was increased in order to allow for a $20 \%$ non-response rate, with an over-representation of subjects with at least 60 years of age, aiming at specific analyses of this age group.

\section{Assessment instrument}

The GENACIS questionnaire was used. It has been developed by a group of researchers form several countries who are interested in comparing alcohol consumption patterns across genders in different contexts and cultures. It has been described elsewhere and used previously in Brazil 16; it consists of 15 sections covering a variety of variables such as socio-demographic characteristics, job experience, social networking, general health and life style, family history of alcohol, mental health, smoking, and alcohol use (quantity, frequency, family context and consequences). A variable labeled "in the workforce" included all those with some form of paid activity, irrespective of being in formal employment or not. The section on general health includes questions about health care, use of medication and services, and some events, such as falls, in the previous year.

Alcohol consumption variables included: number of grams of ethanol consumed per day, 
estimated from self-reported drinking frequency; beverage type; and consumption amounts, based on the ethanol content of standard drinks. Questions about alcohol consumption (beer, wine, liquor, etc.) were standardized to one drink unit of $13 \mathrm{~g}$ of ethanol, which is the average drink size in Brazil. Abstainers were defined as those who did not drink at all during the previous year. Light consumption was defined as 1-2 drinks per day, on average; moderate consumption, as 3-4 drinks per day; heavy consumption was defined as 5 or more drinks per day. All of the above categories were treated as mutually exclusive.

\section{Procedures}

All interviewers had previous experiences with household surveys and were specifically trained and supervised monthly. Ten percent of interviews were double-checked by supervisors for quality control. In order to encourage people to reconsider refusals, letters with information on the objectives, importance and expected impact of the study, were sent as well the credentials and contacts of the main researchers to those who had refused to participate in a first approach. The website address of the project (http://www. viverbem.fmb.unesp.br/pesquisa) was also available for all subjects who wanted more detailed information.

\section{Data analysis}

For the univariate analysis the chi-square test was used ( $p<0.05$; confidence interval of $95 \%$ $95 \% \mathrm{CI})$. The dependent variable was a fall in the previous year. For the multivariate analysis Poisson regression was used, with robust variance, thus obtaining adjusted prevalence ratios (PR) 17 . Age and use of medication were included in all models of Poisson regression. Two models were built. In the first model alcohol categories were "drinkers" and "abstainers", and in the second model all categories of alcohol use were included: abstainers, light, moderate and heavy. Multivariate analyses were conducted separately for each gender.

The project was approved by the Research Ethics Committee of the Faculdade de Medicina de Botucatu at the Universidade Estadual Paulista Júlio de Mesquita Filho on September 13th, 2004.

\section{Results}

Interviews were conducted between October 2005 and March 2007. The final sample included 432 subjects, with a response rate of $74.5 \%$. The average age was 69.5 (standard deviation - SD \pm 7.6), with no differences across gender. The average income was $170(\mathrm{SD} \pm 240)$ dollars per month, and it was noted that $40 \%$ of the elderly contributed $50 \%$ or more to total household income, mainly due to retirement pensions.

Table 1 shows demographic characteristics regarding gender. No gender differences were observed in relation to age $(p=0.78)$. Women had a lower educational level than men: $30.5 \%$ of women reported having never attended school, almost twice as many as men (16.7\%); similarly, only $13 \%$ of women had completed mid-level schooling, as compared to $22 \%$ of men. A majority of men $(81.7 \%)$ were married, whereas among women widowers predominated $(45.6 \%)$, followed by those who were married (39.2\%).

Table 2 compares the pattern and context of alcohol use between genders. In relation to the use of alcohol, more women $(68.4 \%)$ than men (23.6\%) were lifetime abstainers. The frequency of being a former drinker was higher among men (38\%) than among women (17.5\%). Among drinkers, there were more men than women in all categories. Only men reported to be heavy drinkers: $8.3 \%$ of them. There were also differences in relation to the drinking context: $40 \%$ of men reported drinking during meals, weekly or more, whereas only $18.9 \%$ of women reported that pattern. Drinking in bars or pubs, once or more a week, was reported by just $13.8 \%$ of men.

Table 3 shows the bivariate analysis for the occurrence of falls reported by 106 subjects (24.9\%) in the year prior to the interview. There were no associations between falls and gender $(p=0.14)$, being in the workforce $(p=0.17)$, use of psychoactive medication $(\mathrm{p}=0.25)$ nor with pattern of alcohol use $(\mathrm{p}=0.17)$. The only significant variable was being over 70 years of age, which increased the chance of falling $(p=0.03)$.

Table 4 shows the final models of the Poisson regression with falls as the outcome. The multivariate analysis for women showed no association with alcohol use $(p=0.86)$. The models constructed for men showed an association between falls and alcohol use just in the second model, in which the categories were separated from one another. The ingestion of five or more drinks on a typical day tripled the risk for falls during the previous year ( $\mathrm{PR}=3.12$; 95\%CI: 1.49-6.53). 
Table 1

Socio-demographic characteristics and alcohol use, by gender, among subjects aged 60 years or more in the Metropolitan Region of São Paulo, Brazil.

\begin{tabular}{|c|c|c|c|c|c|c|}
\hline & \multicolumn{2}{|c|}{ Male } & \multicolumn{2}{|c|}{ Female } & \multirow{2}{*}{$\begin{array}{c}\text { Total } \\
\mathbf{n}\end{array}$} & \multirow[t]{2}{*}{$p$ value } \\
\hline & $\mathrm{n}$ & $\%$ & $\mathrm{n}$ & $\%$ & & \\
\hline Total & 169 & 40.1 & 263 & 59.9 & 432 & \\
\hline Age (years) & & & & & & 0.78 \\
\hline $60-74$ & 128 & 75.7 & 196 & 74.5 & 324 & \\
\hline $75+$ & 41 & 24.3 & 67 & 25.5 & 108 & \\
\hline Education * & & & & & & 0.001 \\
\hline No schooling & 28 & 16.7 & 80 & 30.5 & 108 & \\
\hline Up to 11 years & 103 & 61.3 & 148 & 56.5 & 251 & \\
\hline 12 years or more & 37 & 22.0 & 34 & 13.0 & 71 & \\
\hline Marital status & & & & & & $<0.001$ \\
\hline Married & 138 & 81.7 & 103 & 39.2 & 241 & \\
\hline Widowed & 16 & 9.5 & 120 & 45.6 & 136 & \\
\hline Divorced/Separated & 9 & 5.3 & 24 & 9.1 & 33 & \\
\hline Single & 6 & 3.5 & 16 & 6.1 & 22 & \\
\hline In the work force & & & & & & $<0.001$ \\
\hline Yes & 51 & 30.2 & 30 & 11.4 & 81 & \\
\hline No & 118 & 69.8 & 233 & 88.6 & 351 & \\
\hline
\end{tabular}

* 2 subjects missing.

Table 2

Pattern of alcohol use and context among elderly in the Metropolitan Region of São Paulo, Brazil $(n=432)$.

\begin{tabular}{|c|c|c|c|c|c|c|c|}
\hline & \multicolumn{2}{|c|}{ Male } & \multicolumn{2}{|c|}{ Female } & \multicolumn{2}{|c|}{ Total } & \multirow[t]{2}{*}{$\mathrm{p}$ value } \\
\hline & $\mathrm{n}$ & $\%$ & $\mathbf{n}$ & $\%$ & $\mathbf{n}$ & $\%$ & \\
\hline Pattern of alcohol consumption (per day) & & & & & & & 0.001 \\
\hline Lifetime abstainer & 40 & 23.6 & 180 & 68.4 & 220 & 50.9 & \\
\hline Former drinker & 64 & 38.0 & 46 & 17.5 & 110 & 25.5 & \\
\hline 1-2 drinks & 40 & 23.6 & 37 & 14.1 & 77 & 17.8 & \\
\hline 3-4 drinks & 11 & 6.5 & 0 & - & 11 & 2.6 & \\
\hline 5 or more drinks & 14 & 8.3 & 0 & - & 14 & 3.2 & \\
\hline Frequency of drinking at meals * & & & & & & & 0.03 \\
\hline Less than weekly & 39 & 60.0 & 30 & 81.1 & 68 & 67.0 & \\
\hline Weekly or more & 26 & 40.0 & 7 & 18.9 & 33 & 33.0 & \\
\hline Frequency of drinking in a bar or pub * & & & & & & & 0.02 \\
\hline Less than weekly & 56 & 86.2 & 37 & 100.0 & 92 & 92.8 & \\
\hline Weekly or more & 9 & 13.8 & 0 & - & 9 & 8.2 & \\
\hline
\end{tabular}

* Only among drinkers (101 subjects). 
Table 3

Prevalence of falls in the previous 12 months among the elderly by covariates, Metropolitan Region of São Paulo, Brazil $(n=106)$.

\begin{tabular}{|c|c|c|c|c|}
\hline & \multicolumn{2}{|c|}{ Falls } & \multirow{2}{*}{$\begin{array}{c}\text { Total } \\
n\end{array}$} & \multirow[t]{2}{*}{$p$ value } \\
\hline & $\mathrm{n}$ & $\%$ & & \\
\hline Gender & & & & 0.11 \\
\hline Male & 33 & 20.7 & 169 & \\
\hline Female & 73 & 28.0 & 263 & \\
\hline Age (in years) & & & & 0.03 \\
\hline $60-69$ & 53 & 20.9 & 146 & \\
\hline 70 or more & 53 & 30.5 & 185 & \\
\hline In the work force & & & & 0.17 \\
\hline Yes & 15 & 19.5 & 81 & \\
\hline No & 91 & 26.2 & 351 & \\
\hline Use of medication & & & & 0.25 \\
\hline No & 91 & 24.1 & 382 & \\
\hline Yes & 15 & 32.1 & 49 & \\
\hline Pattern of alcohol consumption (per day) & & & & 0.17 \\
\hline Abstainer & 83 & 25.8 & 330 & \\
\hline 1-2 drinks & 14 & 17.2 & 77 & \\
\hline 3-4 drinks & 3 & 25.0 & 11 & \\
\hline 5 or more drinks & 6 & 45.2 & 14 & \\
\hline
\end{tabular}

Table 4

Results of Poisson regression for falls in the previous year among the elderly, by gender and pattern of alcohol use, in Metropolitan Region of São Paulo, Brazil.

\begin{tabular}{lccc}
\hline Variables & PR adjusted * & $95 \% \mathrm{Cl}$ & P value \\
\hline $\begin{array}{l}\text { Female (model 1) } \\
\text { Age }\end{array}$ & 1.02 & $1.00-1.04$ & 0.08 \\
$\quad$ Pattern of alcohol consumption (per day) & 1,00 & - & - \\
$\quad$ Abstainer & 0.95 & $0.53-1.69$ & 0.86 \\
$\quad$ Drinker & & & \\
Male (model 1) & 1.05 & $1.01-1.09$ & 0.007 \\
Age & & & - \\
Pattern of alcohol consumption (per day) & 1.00 & - & 0.37 \\
$\quad$ Abstainer & 0.75 & $0.39-1.41$ & 0.001 \\
$\quad$ Drinker & & & \\
Male (model 2) & 1.05 & $1.01-1.11$ & - \\
Age & & & 0.41 \\
Pattern of alcohol consumption (per day) & 1.00 & - & 0.08 \\
$\quad$ Abstainer & 0.65 & $0.22-1.92$ & 0.002 \\
1-2 drinks & 2.79 & $0.90-8.65$ & $1.49-6.53$ \\
3-4 drinks & 3.12 & & \\
5 or more drinks & & & \\
\end{tabular}

PR: prevalence ratio.

* Adjusted by use of medication, age (in years) and alcohol use (with two different classifications of alcohol use). 


\section{Discussion}

The main finding is the confirmation of a difference in alcohol usage between men and women. In the present study, women were the majority of abstainers and their average alcohol consumption was 1-2 drinks per day. Throughout the lives of most of the women interviewed, drinking was a predominantly male activity, as well as attending school and having a paid job outside the home. Women included the highest frequencies of un-schooled subjects and most of them did not have paid jobs. The association between alcohol use and being male is a constant finding in the literature and attributed more to cultural than biological factors 18 .

The prevalence of heavy drinking in the total sample $(3.2 \%)$ and just among men (8.3\%) were similar to the one found in other Brazilian studies. Mendoza-Sassi \& Beria 8 found $4.3 \%$ of heavy drinking among subjects older than 65 , using the Alcohol Use Disorders Identification Test (AUDIT), in Rio Grande, Rio Grande do Sul State. Almeida Filho et al. ${ }^{19}$, found $6 \%$ prevalence in Salvador, Bahia State, Brazil, in their older category that included subjects aged 55 or more. In a recent general population survey Laranjeira et al. 10 reported that $10 \%$ of the elderly had five or more drinks per sitting. Although the percentage of heavy drinkers among men is lower that the one found by Prais et al. 9, this figure is far from irrelevant. In our study, as well as in Laranjeira et al.'s 10 , the elderly reported drinking more often at home than in bars. In so far as this happens, the elderly are less vulnerable to car accidents and fights, but still vulnerable to other consequences of drinking, such as falls, since the likelihood that they occur at home is higher 20.

Falls are quite frequent events among the elderly, with an impact on their physical health that can result in a series of incapacities 20 , including fear of falling 21 . Ribeiro et al. 21 noted that falls have an influence upon the quality of life of elderly people. Also, $88.5 \%$ of them referred to a fear of falling after the incident 21 . In a follow-up study of old aged people conducted in São Paulo city, Perracini \& Ramos 22 found a prevalence of $32.7 \%$ of falls in the year prior to the interview. Risk factors advanced by the authors include absence of a partner, previous fractures and difficulties with daily life activities, among others. Besides these risk factors, alcohol use could also be a predictive factor for falls. In a longitudinal study conducted in four communities in the USA, Mukamal et al. 23 analyzed 5,841 old people and noticed that drinking 14 drinks and more per week increased the risk of falls by $25 \%$. In Brazil, Coutinho et al. 14 did not find such an association. However they only have information about the frequency of alcohol use and no about quantity. It is important to highlight in our study that there is no association between being a drinker and there being a higher risk of a fall. The higher risk was found just for those who reported a higher use of alcohol.

The association between falls and alcohol seems to be more important than with other psychoactive substances, such as benzodiazepines. In this study, the inclusion of medication in the models of Poisson regression did not change the PR. Kurtzthaler et al. 24 measured the blood level of benzodiazepines and alcohol in old people in emergency rooms after falls; they found that among people aged over 70 , alcohol was a more important factor than benzodiazepines. In the present study, $24.9 \%$ of subjects reported a fall in the year prior to the interview; however the corresponding percentage reached $45.2 \%$ among heavy drinkers, with a clear dose-response gradient across the different patterns of alcohol use.

The small number of papers that examined the association between falls and alcohol among the elderly could have a parallel in clinical settings, with a resulting under identification of the problem. McInnes \& Powell 25 found a tendency to under-diagnose alcohol-related problems in the elderly in three Australian hospitals. According to these authors, there could be many reasons for this under-diagnosing: (i) doctors may perceive their role as treating only acute proble$\mathrm{ms}$, but not the chronic problems associated with alcohol use; (ii) there could be an uneasiness in dealing with the latter; (iii) the investigation of alcohol use may be made difficult by the presence of other health problems; (iv) diagnosis could be influenced by the availability of treatment 22 . In favor of this last explanation is the fact that settings with services specialized in substance dependence had the highest rates of identification 25 . Changes in the metabolism of alcohol observed in the elderly, in addition to the prevalence of hazardous drinking, could justify including specific screening strategies as part of the usual routines of health care staff 26 .

This study has some methodological limitations. The first one is the impossibility of inferring causality from cross-sectional studies, since the outcome and risk factors are assessed simultaneously 27 . A second limitation relates to the fact that the functional impairment and altered gait were not assessed in this survey and could be confounders in the association between alcohol and falls. Gama \& Gómez-Conesa ${ }^{28}$, in a systematic review of studies on multiple risk factors for falls in the elderly, observed that those problems were important risk factors. Also, in a 
case-control study, Carvalho \& Coutinho 29 showed elderly people with dementia had a higher risk of several bone fractures. Finally, a frequent bias in cross-sectional studies is the refusal to participate. In the present study the response rate was slightly lower than expected $(74.5 \%)$, even though it was lower than that observed in a recent cross-sectional study conducted in the same area 10. In large Brazilian cities, household surveys are becoming more and more problematic due to the levels and fear of urban violence, in spite of measures taken to minimize refusals.

In Brazil, problems related to alcohol use by the elderly remain relatively unknown, since there have been few studies about this topic among this age group. The interest in studying drinking patterns and related problems in youth is understandable; however, studies of the elderly are also needed. The magnitude of alcohol-related problems in the elderly is not negligible and, moreover, can be prevented. Additionally there is evidence that early diagnosis and treatment are effective for the elderly 30 .

Longitudinal studies are needed for exploring alcohol use among the elderly, identifying morbidity and mortality associated with this behavior, and studying in greater detail the patterns of alcohol use. Such studies could also help in defining what pattern can be considered "risky" for the elderly, since there is no consensus in the literature in this respect, either 31 .

\section{Resumo}

Este estudo se propõe a identificar o padrão de uso de álcool entre idosos e analisar sua associação com quedas. Foi conduzido um estudo transversal, de base populacional, com amostra estratificada da Região Metropolitana de São Paulo, Brasil, utilizando-se o questionário Gênero, Álcool e Cultura: Um Estudo Internacional (GENACIS). A análise estatística utilizou o teste de qui-quadrado e a regressão de Poisson, com variância robusta. A ocorrência de quedas foi considerada a variável dependente. Entrevistas foram conduzidas com 432 sujeitos, com idade média de 69,5 anos. Em relação ao uso de álcool, 50,9\% nunca haviam feito uso, 25,5\% não bebeu no último ano e

\section{Conclusion}

The prevalence of heavy drinking in this age group was found to be similar to the one found in other Brazilian surveys. It was also possible to confirm the hypothesis of an independent association between falls and drinking five or more drinks on a typical day among elderly men that remained significant even after adjusting for age and medication use. Alcohol abuse among the elderly can have serious consequences for their health and an important impact on the health system. With the increase in life expectancy, particularly in low- and middle-income countries health problems among the elderly have become more relevant. It is crucial not to ignore alcohol use by the elderly. It is also important that it receive the appropriate attention not only in clinical examinations but also in politicians' and researchers' agendas.
23,6\% fizeram uso de álcool no último ano. Entre os bebedores, 14 (13,7\%) relataram uso de risco de álcool. No ano anterior, 24,5\% relataram quedas, que se associou a uso de risco de álcool e a ser mais velho. Embora a relação entre uso de risco de álcool e quedas encontrada neste estudo não permita inferir causalidade, tal associação sustenta a hipótese de que abuso de álcool entre idosos pode estar relacionado a problemas de saúde.

Consumo de Bebidas Alcoólicas; Alcoolismo; Acidentes por Quedas; Idoso 


\section{Contributors}

M. C. P. Lima was responsible for the study design, statistical analysis and interpretation of data, as well as organizing and writing the paper. M. O. Simão and A. M. Tucci were responsible for the study design, supervision, and data collection, assisted with the analysis and interpretation of the data, and drafted the paper. J. B. Oliveira and M. B. Cavariani assisted with the analysis, interpretation of the data, and writing the text. F. Kerr-Correa was responsible for the study design, supervision, and data collection, and also assisted with the analysis, interpretation of data and writing of the paper.

\section{Acknowledgments}

This work was only possible thanks to the support of the Pan American Health Organization (PAHO) and financial support from the São Paulo State Research Foundation (FAPESP; 04/11729-2). J. B. Oliveira received a fellowship from FAPESP (07/56124-9) and M. B. Cavariani from the Brazil Higher Education Consortia Program (CAPES). M. C. P. Lima received a post-doctoral fellowship from CAPES (BEX 3552/07-1). Comments and suggestions by Albina Rodrigues Torres, Ana Teresa Abreu Ramos-Cerqueira, José Manoel Bertolote and Jürgen Rehm in different phases of the study were of great value.

\section{References}

1. Lloyd-Sherlock P. Population ageing in developed and developing regions: implications for health policy. Soc Sci Med 2000; 51:887-95.

2. Carvalho JAM, Rodríguez-Wong LL. A transição da estrutura etária da população brasileira na primeira metade do século XXI. Cad Saúde Pública 2008; 24:597-605.

3. Veras R. Envelhecimento populacional contemporâneo: demandas, desafios e inovações. Rev Saúde Pública 2009; 43:548-54.

4. Hulse GK. Álcool, drogas e muito mais entre os idosos. Rev Bras Psiquiatr 2002; 24 Suppl 1:34-41.

5. Paskulin LMG, Vianna LAC. Perfil sócio-demográfico e condições de saúde auto-referidas de idosos de Porto Alegre. Rev Saúde Pública 2007; 41: 757-68.

6. National Institute on Alcohol use and Alcoholism. Alcohol and aging. Alcohol Alert 1998; (40). http:// pubs.niaaa.nih.gov/publications/aa40.htm.

7. Merrick EL, Horgan CM, Hodgkin D, Garnick DW, Houghton SF, Panas L, et al. Unhealthy drinking patterns in older adults: prevalence and associated characteristics. J Am Geriatr Soc 2008; 56:214-23.

8. Mendoza-Sassi RA, Beria JU. Prevalence of alcohol use disorders and associated factors: a populationbased study using AUDIT in southern Brazil. Addiction 2003; 98:799-804.

9. Prais HAC, Loyola-Filho AI, Firmo JOA, LimaCosta, MF, Uchoa E. A population-based study on binge drinking among elderly Brazilian men: evidence from the Belo Horizonte and Bambui health surveys. Rev Bras Psiquiatr 2008; 30:118-23.

10. Laranjeira R, Pinsky I, Zaleski M, Caetano R. II levantamento nacional sobre os padrões de consumo de álcool na população brasileira. Brasília: Secretaria Nacional Antidrogas; 2007. 
11. Fingerhut LA, Anderson RN. The three leading causes of injury mortality in the United States, 1999-2005. NCHS Health E-Stats 2008; March. http://www.cdc.gov/nchs/products/pubs/pubd/ hestats/injury99-05/injury99-05.htm.

12. Sorock GS, Chen LH, Gonzalgo SR, Baker SP. Alcohol-drinking history injury in older adults. Alcohol 2006; 40:193-9.

13. Malvimaara A, Heliövaara M, Knekt P, Reunanen A, Eromaa, A. Risk factors for injurious falls leading to hospitalization or death in a cohort of 19,500 adults. Am J Epidemiol 1993;138:384-94.

14. Coutinho ESF, Fletcher A, Bloch KV, Rodrigues LC. Risk factors for falls with severe fracture in elderly people living in a middle-income country: a case control study. BMC Geriatr 2008; 8:21.

15. Taylor B, Rehm J, Aburto JTC, Bejarano J, Cayetano C, Kerr-Corrêa F, et al. Alcohol, gender, culture and harms in the Americas: PAHO Multicentric Study final report. Washington DC: Pan American Health Organization; 2007.

16. Kerr-Corrêa F, Tucci AM, Hegedus AM, Trinca LA, Oliveira JB, Floripes TMF, et al. Drinking patterns between men and women in two distinct Brazilian communities. Rev Bras Psiquiatr 2008; 30:235-42.

17. Coutinho LMS, Scazufca M, Menezes PR. Métodos para estimar razão de prevalência em estudos de corte transversal. Rev Saúde Pública 2008; 42:992-8.

18. Wisnack SC, Wilsnack RW. International gender and alcohol research: recent findings and future directions. Alcohol Res Health 2002; 26:245-50.

19. Almeida-Filho N, Lessa I, Magalhães L, Araújo MJ, Aquino E, Kawachi I, et al. Alcohol drinking patterns by gender, ethnicity, and social class in Bahia, Brazil. Rev Saúde Pública 2004; 38:45-54.

20. Fabrício SCC, Rodrigues RAP, Costa Junior ML Causas e conseqüências de quedas de idosos atendidos em hospital público. Rev Saúde Pública 2004; 38:93-9.
21. Ribeiro AP, Souza ER, Atie S, Souza AC, Schilithz AO. A influência das quedas na qualidade de vida de idosos. Ciênc Saúde Coletiva 2007; 13:1265-73.

22. Perracini MR, Ramos LR. Fatores associados a quedas em uma corte de idosos residentes na comunidade. Rev Saúde Pública 2002; 36:709-16.

23. Mukamal KJ, Mittleman MA, Longstreth WT, Newman AB, Fried LP, Siscovick DS. Self-reported alcohol consumption and falls in older adults: cross-sectional and longitudinal analyses of the cardiovascular health study. J Am Geriatr Soc 2004; 52:1174-9.

24. Kurzthaler I, Wambacher M, Golser K, Sperner G, Sperner-Unterweger B, Haidekker A, et al. Alcohol and benzodiazepines in falls: an epidemiological view. Drug Alcohol Depend 2005; 79:225-30.

25. McInnes E, Powell J. Drug and alcohol referrals: are elderly substance abuse diagnoses and referrals being missed? BMJ 1994; 308:444-6.

26. Dar K. Alcohol use disorders in elderly people: fact or fiction? Advances in Psychiatric Treatment 2006; 12:173-81.

27. Prince M. Cross-sectional surveys. In: Prince $M$, Stewart R, Ford T, Hotpf M, editors. Practical psychiatric epidemiology. Oxford: Oxford University Press; 2003. p. 111-29.

28. Gama ZAS, Gómez-Conesa A. Factores de riesgo de caídas en ancianos: revisión sistemática. Rev Saúde Pública 2008; 42:946-56.

29. Carvalho AM, Coutinho ESF. Demência como fator de risco para fraturas graves em idosos. Rev Saúde Pública 2002; 36:448-54.

30. Oslin DW, Pettinat H, Volpicelli JR. Alcoholism treatment adherence: older age predicts better adherence and drinking outcomes. Am J Geriatr Psychiatry 2002; 10:740-7.

31. Lang I, Guralnik KJ, Wallace RB, Melzer D. What level of alcohol consumption is hazardous for older people? Functioning and mortality in U.S. and English National Cohorts. J Am Geriatr Soc 2007; 55:49-57.

Submitted on $12 /$ Jan/2009

Final version resubmitted on 04/Aug/2009

Approved on 03/Sep/2009 